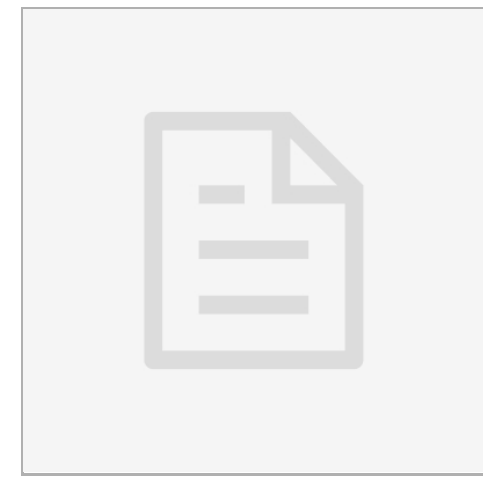

NOV 05, 2019

\section{open $\boldsymbol{\text { ACCESS }}$}

DOI:

dx.doi.org/10.17504/protocol s.io.7uphnvn

Protocol Citation: Ida Barlow 2019. genotyping_PCR. protocols.io

https://dx.doi.org/10.17504/p rotocols. io. 7 uphnvn

License: This is an open access protocol distributed under the terms of the Creative Commons Attribution License, which permits unrestricted use, distribution, and reproduction in any medium, provided the original author and source are credited

Protocol status: Working We use this protocol and it's working

Created: Oct 01, 2019

Last Modified: Nov 05, 2019

PROTOCOL integer ID:

28271

Keywords: PCR

\section{(3) genotyping_PCR}

\section{Ida Barlow ${ }^{1}$}

${ }^{1}$ Imperial College London

\section{Behavioural Genomics}<smiles>C1CCCCCCCC1</smiles>

Ida Barlow

\section{ABSTRACT}

Protocol for doing PCR on single worm lysate. This is a basic protocol that can be adapted according to specific primers and amplicon size.

\section{MATERIALS}

\section{MATERIALS}

88 custom made primers Contributed by users

\&8 Taq PCR Master Mix Kit Qiagen Catalog \#Cat No./ID: 201443

\title{
PCR program
}


1 Precalculate how many reactions are required for each pair of primers. Remember to include a minus-template control and add 1 to the final number to make sure you don't run out of reagents

Note

1X reaction:

\ $12.5 \mu \mathrm{L}$ QIAGEN 2X Taq PCR master mix

\ $2 \mu \mathrm{L}$ primer mix

\ $2 \mu \mathrm{L}$ genomic DNA

$\triangle 8.5 \mu \mathrm{L}$ water

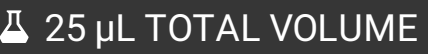

Eg. for 6 reactions, need to prepare $(6+1) X$ reactions

\section{Prepare reagents}

2 Get PCR master mix and gDNA out of the freezer. Thaw PCR mix on ice and spin down to collect at the bottom of the tube.

3 Get primers out of freezer or prepare new primers

3.1 If primers are ordered new, resuspend lypholised oligo to $[\mathrm{M}] 100$ micromolar $(\mu \mathrm{M}) \quad(==100$ $\mu \mathrm{mol} / \mathrm{l})$. Volume of water (in $\mu \mathrm{l}$ ) to add is calculated as Volume $=$ nmol $* 10$ Eg. for primer provided as $28.5 \mathrm{nmol}$, add $285 \mu$ of MQ water

3.2 If diluting from stock primers, make a a primer mix of $10 \mu \mathrm{M}$ of each the forward and reverse primer.

Eg. $\triangle 80 \mu \mathrm{L}$ water $+\triangle 10 \mu \mathrm{L}(100 \mu \mathrm{M}) \mathrm{FW}$ primer $+\varangle 10 \mu \mathrm{L}(100 \mu \mathrm{M})$ REV primer $=$ TOTAL \& $100 \mu \mathrm{L}$ primer mix

$4 \quad$ Prepare and label PCR tubes 


\section{Assemble reagents}

6 Assemble reagents in master mix tube in following order:

1. Water

2. Primers

3. Taq PCR master mix

7 Dispense $\triangle 23 \mu \mathrm{L}$ PCR mix into each PCR tube

8 Add $₫ 2 \mu \mathrm{L}$ genomic DNA to the PCR tube.

9 Close tubes, make sure the lids are firmly sealed, and flick to ensure all liquid is at the bottom of the tube

\section{PCR program}

10 Put the PCR tubes in the thermocycler and run with the geno-PCR program 
Note

Heat lid:

$b^{\circ} 105^{\circ} \mathrm{C}$

Initial denaturation:

(3) 00:03:00 $\quad 8^{\circ} 93^{\circ} \mathrm{C}$

35 cycles:
1. $00: 00: 30 \quad 8^{\circ} 93^{\circ} \mathrm{C}$
2. 00:00:30 $88^{\circ} 55^{\circ} \mathrm{C}$ adjust temperature according to primers
3. 00:01:00 $88^{\circ} 72^{\circ} \mathrm{C}$ adjust time according to amplicon size. Rule: $1 \mathrm{~min}$ per $1 \mathrm{~kb}$

Final extension:

(3) 00:10:00 $\quad 8^{\circ} 72^{\circ} \mathrm{C}$

Final Hold:

if $10^{\circ} \mathrm{C}$ 